\title{
The Effect of Halal Product Knowledge, Halal Awareness, Perceived Psychological Risk and Halal Product Attitude on Purchasing Intention
}

\begin{abstract}
Abdulkadir Ozturk ${ }^{\mathrm{a}}$
Abstract: It is considered that individuals should know the concept of halal and be aware of the conditions that make a product halal in order for consumers to have the intention to purchase halal products. The aim of this study is to find out the attitudes and purchase intentions of consumers towards halal chicken products under the model of knowledge, attitude and practice (KAP). It also aimed to determine consumers' halal awareness of halal chicken products and the effect of perceived psychological risk on purchase intention. The data required for the study were collected from the individuals who purchased chicken using convenience sampling method through an online questionnaire form. The data collection process was completed with the participation of 410 people assumed to represent the universe. The research model and hypotheses between variables were tested using the structural equation modeling method. The results of the analysis show that knowledge about halal products, awareness of halal products, and perceived psychological risk have a significant and positive influence on attitudes toward halal chicken products. In addition, attitudes towards halal chicken products, awareness of halal products, and perceived psychological risk were found to have a significant and positive influence on purchase intention.
\end{abstract}

\begin{abstract}
Keywords: Halal Product Knowledge, Halal Awareness, Perceived Psychological Risk towards Halal Products, Attitude towards Halal Products, Intention to Purchase Halal Products

JEL: M30, M31

$\begin{array}{ll}\text { Received } & : 28 \text { October } 2021 \\ \text { Revised } & : 11 \text { December2021 } \\ \text { Accepted } & : 06 \text { January } 2022 \\ \text { Type } & : \text { Research }\end{array}$
\end{abstract}

\section{Introduction}

$31.11 \%$ of the world's population (out of 7.79 billion) are Christians, $24.90 \%$ are Muslims, $15.16 \%$ are Hindus and $6.62 \%$ are Buddhists. It has been found that $90 \%$ of Buddhists and Hindus, $75 \%$ of Muslims, and $16 \%$ of Jews living in the United States of America (USA) follow religious prohibitions regarding food (Bonne \& Verbeke, 2008: 35). Considering that the Muslim population in the world is about 2 billion, it is clear that one in four consumers in the world prefer Halal products. Halal is an Arabic word that means permitted, allowed, lawful in Islam. "The halal market includes food products and food services, as well as pharmaceuticals, cosmetics, personal care products, cleaning agents, packaging material, animal and poultry feed, hospitality and tourism, modest clothing and logistics" (International Halal Certification, 2021). According to a verse in the Qur'an, the holy book of Islam, "O people! Eat the lawful and clean substances in the earth; do not follow the devil, because it is your obvious enemy" (The Holy Qur'an, Surah Al-Baqarah, verse 168). With this verse, the Qur'an calls upon mankind to eat and drink from halal and clean things and not to engage in harams by following the footsteps of the devil. Since this command is accepted by all Muslims in the world, the target group of Muslim consumers meets on a common ground. This common

a Asst. Prof., PhD., Recep Tayyip Erdogan University, Faculty of Economics and Administrative Sciences, Department of Business Management, Rize, Turkiye, abdulkadir.ozturk@erdogan.edu.tr (ORCID ID: 0000-0002-1855-8892) 
ground is seen as a great advantage for the marketers (Nurhayati \& Hendar, 2019). Because it is exactly what the target market wants. Therefore, marketing efforts aimed at this target market will be more homogeneous.

It is estimated that Muslims spent 2.02 trillion US Dollars in 2019 on food, medicine, cosmetics, fashion, travel and media/recreation. Spending on food alone was put at 1.17 trillion US Dollars. Moreover, it is estimated that the global halal food market will reach 3 trillion US Dollars by 2023 (Statista, 2021a). All these expenditures are believed to be inspired by the Islamic faith (Salaam Gateway, 2020). Many countries around the world are trying to create Islamic-based economic ecosystems. Malaysia currently tops the overall ranking of the Global Islamic Economy Indicator (GIEI) for the eighth consecutive year, while Saudi Arabia is in second place, followed by the United Arab Emirates (UAE) and Indonesia. It is entering into strategic partnerships to expand halal trade in Indonesia and the Philippines, as are Japan and Malaysia. Pakistan, Qatar and Kuwait have announced their plans for new central regulations in the Islamic finance sector. Examining investment in the global halal food market, it is reported that German companies are investing more in the halal food, pharmaceutical and cosmetics sectors in 2020 than in previous years (Loho, 2020). Not only European companies like Germany, England and France, but also many countries around the world are striving to get a share of the halal food sector. For example, Australia is the 9th largest Islamic economic exporter in halal food production, exporting more than 5.3 billion US Dollars to Gulf Cooperation Council (GCC) countries (Salaam Gateway, 2020). Brazil, India, Turkey, France, and the United States are the largest exporters from the member countries of the Organization of Islamic Cooperation (OIC) (Statista, 2021b). These statistics show how large and one of the fastest growing markets is the market for halal products. What needs to be considered in marketing is the importance of people's religious beliefs in their daily lives and the influence of religious principles on purchasing decisions. Considering how religious beliefs and sensitivities influence consumers' purchasing decisions, it is inevitable for companies to take these sensitivities into account.

According to the June 2021 poultry production report of the Turkish Statistical Institute (TURKSTAT), chicken meat production in Turkey in June 2021 is 193,604 tons (TURKSTAT, 2021). According to the report of the Ministry of Agriculture and Forestry of the Republic of Turkey on chicken meat in agricultural product markets in June 2021, Turkey is a country that meets the demand of chicken meat in the domestic market and is an exporter of chicken meat. $49.1 \%$ of the 151 thousand tons of chicken meat exported in the first quarter of 2021 was made to Iraq (Directorate of Agricultural Economy and Policy Development Institute of the Ministry of Agriculture and Forestry of Turkish Republic, 2021). Considering the majority Muslim domestic market and export markets, chicken producers in Turkey should give more importance to halal. Companies such as GIMDES, TSE, HEDEM, Helalder, Dünya Helal Birliği in Turkey issue halal certificates (Halal Platform, 2018). According to the December 2021 data, there are 42 companies in Turkey that have received certificates from GIMDES, one of the certificate issuers (GIMDES, 2021).

In Turkey, where this study was conducted, there are many studies on halal foods, especially on consumers' perceptions (Kurtoğlu \& Çiçek, 2013), attitudes (Özçelik Yorulmaz \& Akçi, 2020), willingness to pay more for halal foods (Çukadar, 2017; Madenci et al., 2020), awareness of halal-certified products (Kızgın \& Özkan, 2014; Özdemir \& Yaylı, 2014), and purchase intentions (Öztürk et al., 2015).

Many facts affect consumer behavior, but knowledge, awareness, and sensitivity to religious issues can have a greater effect on purchasing preferences. Companies that are aware of the power of religious values can influence the consumer masses with promotion strategies based on the religious sentiments of individuals. This strategy is successful when it appeals to all consumers of that religion, not just a target audience with a high level of religiosity. For this reason, companies that want to target the Muslim consumer market should become aware of the market by raising awareness of an issue where there is a common sensibility, such as halal products (Dindyal \& Dindyal, 2003). However, the fact that there are some rules for halal production in practice increases the costs of companies (Vanany et al., 2021). For this reason, although some companies are reluctant to offer halal production conditions, they cannot escape the growing awareness and demand for halal. Moreover, halal products are in high demand among non-Muslim consumers due to their commitment to safety, hygiene, food quality and health (Alam \& Sayuti, 2011). This 
demand has led many international companies to adopt halal production systems (ResearchAndMarkets, 2021).

When the global halal food market is segmented on the basis of product type, it is categorized into grain-based food, fruits and vegetables, milk and dairy, meat, poultry, and seafood. However, the most demanded halal certificate in the market currently is for meat and meat products (ResearchAndMarkets, 2021). Although chicken meat is the most commonly sourced meat globally (OECD, 2021), the current literature focuses on general food products. Therefore, this study is one of the preliminary studies that investigates consumer purchase intentions for halal food products containing chicken meat.

A research model was created by adding the variables "halal awareness" and "perceived psychological risk" to the Knowledge, Attitude, and Practice (KAP) model, which is used in many fields to study human behavior. In this study, it is predicted that halal awareness will increase when consumers have more information about the halal conditions of the products. It is also hypothesized that increased knowledge about halal products will cause the person to have psychological concerns about whether the products meet halal requirements. It is predicted that perceived psychological risk along with knowledge and awareness of halal products may have an effect on consumer attitudes towards halal products. Based on these predictions, the aim of the study is to determine the effect of attitude, awareness, and perceived psychological risk on purchase intention for halal products.

In light of this information, the study first provided literature references on the variables. Then, the explanations and results of the hypotheses showing the relationships between the variables are presented. Finally, the results obtained are discussed.

\section{Literature Review}

The concept of halal is a term used in the, the holy book of the Islamic religion (The Holy Qur'an, Surah Al-Ma'idah, verse 88). According to Islam, it means that it is not forbidden to do, eat or drink anything. The opposite of halal is "haram". On the other hand, "haram" refers to actions and practices that are forbidden by the religion (Alam \& Sayuti, 2011). The products that are preferred by Muslims in accordance with the points mentioned in the Quran are called halal products (Abd Rahman et al., 2015: 149). According to the rules laid down in the Qur'an and the Hadith, the following are forbidden to Muslims: animals that have died before slaughter (carrion), pork or pork products, animals that have not been slaughtered in the name of Allah or according to Islamic methods, blood and blood products, products of animals such as carnivores and predators, and alcohol and products containing alcohol (The Holy Qur'an, Surah Al-An'am, verse 145). Today, the importance of the market for halal products is gradually increasing as Muslims, who form a large market throughout the world, consider the implications of religious beliefs in their consumption. Commercially, halal markets for Muslim consumers are the fastest growing markets in the world (Bashir, 2019). Combined with religious enthusiasm and belief, halal food is perceived by consumers as cleaner, healthier, tastier, and conforms to religious rules (Abd Rahman et al., 2015: 149). According to the results of a research conducted by Kızlkaya (2017) on consumers' tendency towards halal food, she found that there is a sensitivity towards halal food in Turkey.

The theoretical basis for the development of the hypothesis relationships is the knowledge, attitude, and practice (KAP) model. The KAP model states that knowledge has a positive effect on a person's attitude and that attitude influences practice or behavior (Kwol et al., 2020: 2)

Knowledge, attitude and practice (KAP) surveys were first conducted in the 1950 s to find out how the concept of family planning was received, understood and applied in different societies around the world (Launiala, 2009: 1). Later studies found that the KAP model was preferred in many food safety studies (Baser et al., 2017; Kwol et al., 2020; Taha et al., 2020). According to KAP surveys, knowledge forms attitude and both knowledge and attitude form the building blocks of practice. In general, KAP surveys are considered to provide a conceptual framework for measuring participants' understanding, awareness, readiness and commitment to a particular topic (Ahmad et al., 2015: 285). Accordingly, it can be said that consumers' 
knowledge about halal products will influence their attitude towards halal products, their halal awareness and their intention to use halal products.

The research model created using the literature review consists of the following variables.

\subsection{Halal Knowledge}

The information about halal products is permission and prohibition that people must know and follow in order to make their consumption in accordance with the rules of the Islamic religion (Nurhayati \& Hendar, 2019: 608). From the interpretation of the 173rd verse of Surah Al-Baqarah of the Qur'an, "Allah has forbidden you only dead animal flesh, blood, pork, and that which has been slaughtered in the name of other than Allah" (The Holy Qur'an, Surah Al-Baqarah, verse 173), the following four halal products emerge: (1) The meat of an animal that died spontaneously or was killed without being properly slaughtered is haram, (2) the blood that flows from the body of an animal, living or dead, is haram, even if its meat is eaten, (3) pork is haram, (4) the meat of an animal slaughtered in the name of other than Allah is haram (Karaman et al., 2020: 257-260). In order for consumers to realize their awareness and attitude towards halal products, it is the most important requirement that they have this halal knowledge. Nurhayati \& Hendar (2019) concluded in their study that halal product information positively influences halal awareness. Based on these findings, the following hypothesis was developed:

\section{$H_{1}$ : Halal product knowledge has a positive and significant effect on halal awareness.}

As consumers' halal knowledge increases, the desire to investigate the halal status of products arises. This is because knowledge is the first stage of persuasion. For persuasion to occur easily, there should be no suspicious situation (Rogers, 2003). When a person perceives a risk in any condition, he or she may be affected by it and try to minimize the risk and reduce the complexity of the condition (Bauer, 1960). The reason is that consumers try to avoid mistakes in order to gain an advantage from the act of purchase (Mitchell, 1999: 163). Today, halal certificate comes to the fore as a tool to eliminate the consumer's distrust of having halal knowledge in food products. Although the halal logo plays an important role in eliminating the perceived psychological risks related to the legality of these products, it is not sufficient for some consumers. Wilson and Liu (2011: 37) noted that Muslim consumers have knowledge about halal and are sensitive in their food and beverage choices because of this knowledge. For this reason, they argued that consumers with more halal knowledge and awareness would perceive more risks. Accordingly, the following hypothesis was developed:

\section{$\mathrm{H}_{2}$ : Halal product knowledge has a positive and significant effect on perceived psychological risk.}

An attitude is a person's relatively comprehensive and continuous evaluation of an object, subject, person, or action (Hoyer \& Maclnnis, 1997: 114). To form an attitude requires cognition, which provides information about the event, object, or phenomenon about which an attitude is to be developed. This is because a person cannot develop an attitude towards an object or phenomenon about which he or she has no knowledge. Any information disclosed by companies constitutes cognition in potential consumers. Attitudes have a direct effect on the consumer's decisions before, during, and after the purchase. No one is born with an attitude towards a person, situation, or event because attitudes are the result of learning. For this reason, a Muslim consumer will have a positive attitude towards halal products after acquiring the knowledge about halal. Previous research has proven that knowledge about organic foods has a positive effect on attitudes towards these foods (Stobbelaar et al., 2007; Aertsens et al., 2011). However, there is also a study in the literature where no significant relationship was found between halal knowledge and attitude (Abd Rahman et al., 2015). In line with this information, the following hypothesis was developed:

$H_{3}$ : Halal product knowledge has a positive and significant effect on the attitude towards halal product.

\subsection{Halal Awareness}

Awareness means the ability of a person to know, perceive and feel events, that is, to be aware of something (Nurhayati \& Hendar, 2019: 605). To be aware of this awareness of halal products, the person 
must have halal product knowledge. The consumer who knows the conditions of being halal and is aware of halal products listed in the four articles mentioned above will be able to develop an attitude towards halal products with this awareness (Akın \& Okumuş, 2021: 4). Thus, awareness in the case of halal could be conceptualized as the process of providing information to raise awareness about what Muslims are allowed to eat and drink (Ambali \& Bakar, 2014). In this regard, halal awareness, similar to brand awareness which explains consumers' ability to identify and remember brands under different conditions, can be interpreted as consumers' ability to identify and remember halal products under different conditions. (Nurhayati \& Hendar, 2019). It is believed that there is a relationship between consumer awareness and food consumption behavior (Özsacmacl, 2018). It was found that awareness of halal foods influences attitudes towards halal foods even in the non-Muslim sample (Golnaz et al., 2010: 673). Based on these findings, it was hypothesized that:

$\mathrm{H}_{4}$ : Halal awareness has a positive and significant effect on attitude towards halal product.

Awareness can be considered the first step of the purchasing process. At this stage, the consumer, who does not have enough information about the product, starts to get to know the product as he/she gets information. Then, they make their selection among the alternatives according to the criteria they have determined. The criterion of the consumer, especially in food products, is that the products are halal in Muslim societies. For this reason, Muslim consumers will tend to prefer halal products (Zakaria et al., 2017). Consumers with high religious sensitivity tend to perform their daily activities within the framework of religious criteria. For this reason, they tend to be impulsive when buying and have a greater awareness of halal (Shah Alam et al., 2011). However, contrary to popular belief, most businesses in Muslim countries do not use halal logos and halal certificates. Because it is assumed that all products produced in Muslim countries are halal, the halalness of the products is often not questioned (Rizkitysha \& Hananto, 2020). However, even if the food scandals that have emerged in recent years have partially reversed this situation, these scandals are forgotten after a while. With the promotion efforts of businesses, they try consumers to focus on price, taste, and color elements rather than the halal logo of the product. For this reason, it is thought that halal awareness in Muslim countries is an important factor that needs to be examined. Aziz and Chok (2013), Nurhayati and Hendar (2019), Mutmainah (2018), and Yasid and Andriansyah (2016) found a positive relationship between halal product awareness and intention to purchase halal products in their studies. The findings of previous studies confirm that awareness of halal foods has a positive effect on consumers' purchase intentions. Based on the literature, the $\mathrm{H}_{7}$ hypothesis was developed as follows:

\section{$H_{7}:$ Halal awareness has a positive and significant effect on purchase intention.}

\subsection{Perceived Psychological Risk}

One of the important pieces of evidence impacting consumer behavior is perceived risk. The degree of risk perceived by a consumer for the product to be bought determines the behavior and level of research about the product. The risks related to the consumer buying decision process can be examined under five headings. These are: Financial risk, functional risk, physical risk, social risk, and psychological risk (Stone \& Mason, 1995: 137). Psychological risk is defined as "The risk that the selection of performance of the producer will have a negative effect on the consumer's peace of mind or self-perception" (Kim et al., 2005: 38). Psychological risk is also related to the frustration of making a bad choice and the loss of psychological balance (Ashford et. al, 2000). Therefore, the possibility that the consumer buys a non-halal product contrary to the Islamic belief will disturb the person psychologically and emotionally (Chen \& Tang, 2013). This psychological risk arises from both the fear of temptation and the consumption of an unhygienic product. Consumers who do not want to take this risk tend towards halal products and show a positive attitude towards halal products.

However, some manufacturers engage in commercial concerns, corruption and unethical practices. As a result of the inspections made by the official authorities, many local and imported foods that do not comply with halal conditions are disclosed to the public every year (Fuseini et. al., 2007: 128). On the other hand, these fears offer a great opportunity to brands that are perceived as reliable (Ireland \& Rajabzadeh, 
2011). Studies generally show that the increase in perceived risk affects attitudes negatively (Akın \& Okumuş, 2021). That is, risk and attitude are inversely proportional. It is because while risk expresses a negative situation, attitude expresses a positive situation. However, the perceived risk in this study is in favor of the consumer. Because if consumers do not perceive the risk of the food they will buy, they will not try to buy halal products. For this reason, the concern that an individual will buy a product that is not halal will lead them to search for a halal product. The hypothesis created in this direction is:

$H_{5}$ : The perceived psychological risk has a positive and significant effect on the attitude towards the halal product.

If the person has halal knowledge, he or she will have some concerns about whether the product is halal. However, if the consumer does not have halal knowledge, he or she will not be concerned about the halal suitability of the products. For this reason, the psychological risks that a person faces by buying a nonhalal product steer the person towards halal products. It is expected that the consumer who wants to get rid of such psychological risks intends to buy halal products. Processed meat products are the category that raises the most halal concerns among Muslim consumers. For these products, Muslim consumers tend to prefer halal brands (Ireland \& Rajabzadeh, 2011). Studies suggest that the higher the perceived risk, the lower the purchase intention (Quintal et al., 2016; Mortimer et. al., 2020). However, in this study, the psychological risk variable is used to avoid a negative situation (fear of purchasing non-halal products). Consumers who perceive a risk that the products are not halal will intend to purchase halal products. Therefore, risk and intention are directly related to each other. In other words, the more consumers are concerned about the halal quality of the products in the market, the stronger their efforts to buy halal products will be. On this basis, the following hypothesis was created:

$H_{8}$ : Perceived psychological risk has a positive and significant effect on purchase intention.

\subsection{Attitude toward Halal Product}

Attitude shows the tendency of the person to react positively or negatively towards the object, person or events (Schiffman \& Kanuk, 2004). Abd Rahman et al. (2015) found a positive relationship between the attitude towards halal cosmetic products and the purchase intention in their study. Arguing that religion plays an effective role in shaping food choice in many societies, Bonne et al. (2007) concluded that the attitude positively affects purchase intention. Similarly, other researchers have found that the attitude towards halal food is related to the intention to consume halal food (Lada et al., 2009; Golnaz et al., 2010; Afendi et al., 2014; Bashir, 2019). According to a study conducted in Turkey, it has been determined that Turkish consumers' attitudes towards halal products have a positive effect on their intention to purchase halal products (Öztürk et al., 2015). In this study, which focuses on the purchase intention of halal chicken meat, the following hypothesis is proposed:

$H_{6}$ : Attitude towards halal product has a positive and significant effect on purchase intention.

\subsection{Purchase Intention}

Purchasing intention refers to the willingness or planning of the consumer to buy a product in the future (Schiffman \& Kanuk, 2004). Purchasing intention is one of the most critical stages of the purchasing process that reveals the consumer's decisive reaction to stimuli. According to Bashir (2019), purchase intention has a significant effect on purchasing behavior towards halal food products. It has been determined that attitudes towards halal food consumption have a positive effect on purchase intention (Özçelik Yorulmaz \& Akçi, 2020). In this context, the consumer's attitude towards halal products will determine their purchase intention.

\section{Research Model and Data Collection}

The research model created in accordance with the conceptual framework of the study is shown in Figure 1. 
Figure 1. Research Model

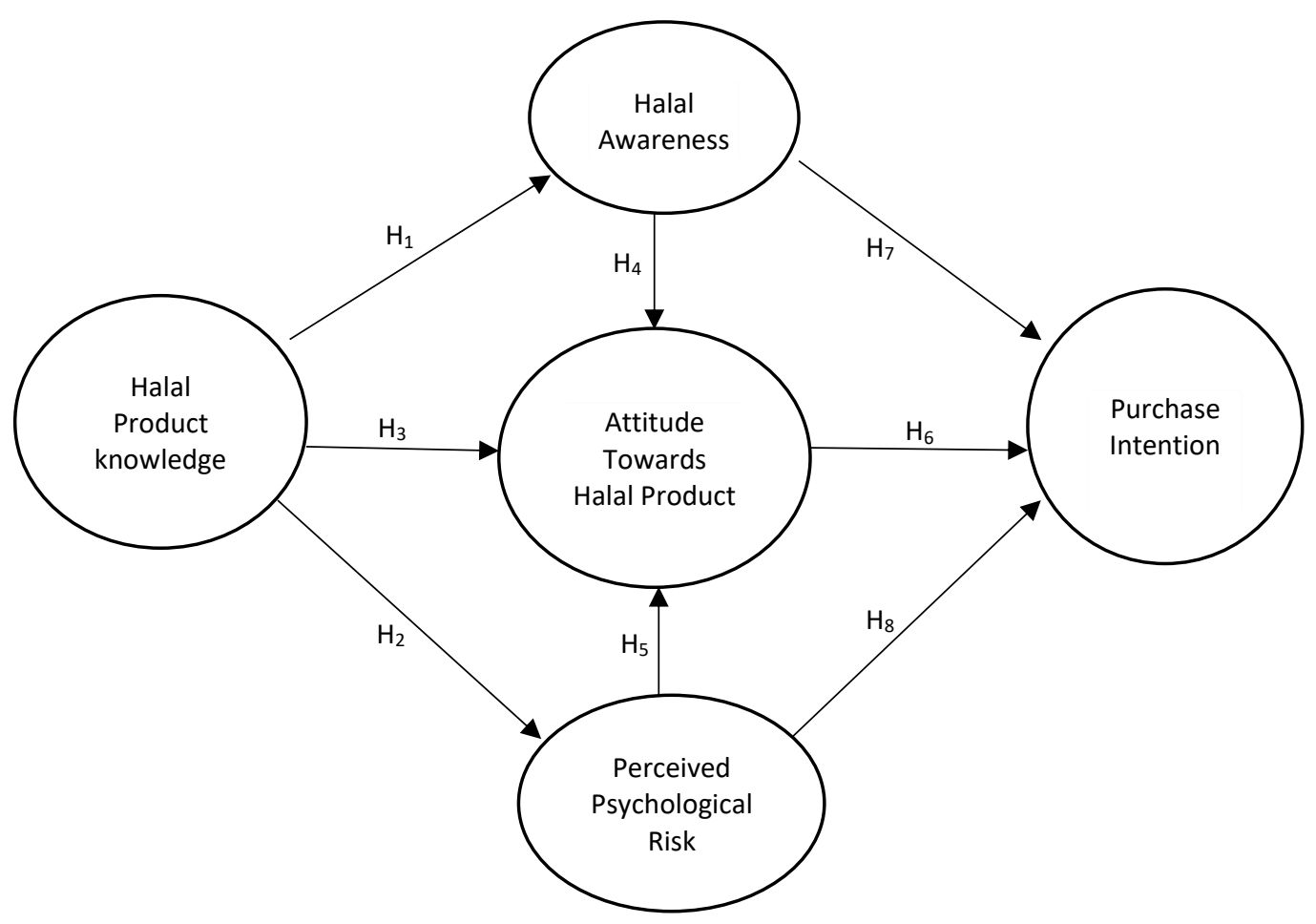

The research population consists of Muslim consumers over the age of 18 who purchase chicken in Rize, Turkey. However, since it was not possible to reach the entire population, the link created to the online survey was sent by the researchers to consumers who consume chicken meat using the convenience sampling method. Each online survey participant was asked to share this link with Muslim consumers who consume chicken meat. This form consists of two parts. The first part contains the expressions of the variables, while the second part contains questions about the demographic characteristics of the participants. A total of 18 statements on knowledge about halal products (4 statements) (Abd Rahman et al., 2015; Nurhayati \& Hendar, 2019), halal awareness (3 statements) (Aziz \& Chok 2013; Nurhayati \& Hendar, 2019), attitude towards halal products (4 statements) (Lada et al., 2009; Abd Rahman et al, 2015; Rizkitysha \& Hananto, 2020), perceived psychological risk (3 statements) (Kim et al., 2005; Mortimer et al., 2020) and purchase intention (4 statements) (Abd Rahman et al., 2015; Nurhayati \& Hendar, 2019; Mortimer et. al., 2020), were included in the study. To test the comprehensibility of the expressions in the study, a plot test study was conducted with a group of 70 people. As a result of the suggestions and criticisms, the online survey form was finalized. This form was designed using the five-point Likert scale $(1=$ strongly disagree, $\ldots$ $5=$ strongly agree) to determine the participants' level of agreement with the statements. The online survey was conducted between April 21, 2021 and May 15, 2021 with the participation of 410 people living in Rize, Turkey. SPSS 22 program was used for frequency and exploratory factor analysis (EFA). AMOS 20 was used for confirmatory factor analysis (CFA) and hypothesis testing analysis with structural equation modeling (SEM).

According to the evaluation report of Recep Tayyip Erdoğan University Social Sciences and Humanities Ethics Committee, dated 20/04/2021 and Meeting Decision Number 2021/103, it is an ethically appropriate study. 


\section{Findings}

\subsection{Demographic Characteristics of Respondents}

Examining the demographic data of the participants, we find that 52.7 percent of the participants are women and 47.3 percent are men. In terms of marital status, it is found that 45.1 percent of the participants are single and 54.9 percent are married. Analysis by age shows that $22.3 \%$ of the participants are $18-24$ years old, $23.7 \%$ are $25-31$ years old, $20.6 \%$ are $32-38$ years old, $19.7 \%$ are $39-45$ years old and $13.7 \%$ are 45 years old and above. In terms of educational level, it can be noted that $20.5 \%$ of the participants have a high school diploma, $25.6 \%$ have an associate degree, $29.4 \%$ have an undergraduate degree, and $24.5 \%$ have a graduate degree (master's and doctoral). In terms of occupation, it is noted that $26.4 \%$ of the participants are working in the public sector, $19.8 \%$ are working in the private sector, $12.9 \%$ are self-employed, $9.8 \%$ are retired and $24 \%$ are students. When considering the income, the distribution of the participants is as follows: $14.4 \%$ of them earn 3000 TL (Turkish Lira) and less, 24.1\% earn 3001-4500 TL, 20\% earn 4501-6000 TL, 17.3\% earn 6001-7500 TL and $23.2 \%$ earn 7501 TL and more. In general, it can be said that the distribution of demographic results is balanced, there is no agglomeration in only one section with any demographic characteristics, and consequently, they can be subjected to a healthy analysis process.

\subsection{Explanatory Factor Analysis}

A five-point Likert scale was used to measure the variables in the model created for the purpose of the study. Explanatory factor analysis (EFA) was conducted to determine the factor structure of the 18 statements in the research sample. Factor loadings, mean participation scores, Cronbach's alpha and variance explanation scores of the expressions as a result of factor analysis are presented in Table 1.

Table 1. Factor Analysis Results for the Variables

\begin{tabular}{|c|c|c|c|c|c|}
\hline & $\begin{array}{c}\text { Average } \\
\text { Participation }\end{array}$ & $\begin{array}{c}\text { Std. } \\
\text { Deviation }\end{array}$ & $\begin{array}{l}\text { Factor } \\
\text { Load }\end{array}$ & $\begin{array}{c}\text { Cronbach } \\
\text { Alfa }\end{array}$ & $\begin{array}{l}\text { Variance } \\
\text { Explained }\end{array}$ \\
\hline Purchase Intention & & & & 0.938 & 18.744 \\
\hline PINT3 & 4.57 & 0.897 & 0.804 & & \\
\hline PINT1 & 4.5 & 0.936 & 0.800 & & \\
\hline PINT2 & 4.6 & 0.823 & 0.794 & & \\
\hline PINT4 & 4.42 & 1.047 & 0.743 & & \\
\hline Attitude Towards Halal Product & & & & 0.901 & 17.441 \\
\hline ATT2 & 4.59 & 0.816 & 0.825 & & \\
\hline ATT1 & 4.67 & 0.788 & 0.788 & & \\
\hline ATT3 & 4.69 & 0.773 & 0.732 & & \\
\hline ATT4 & 4.68 & 0.789 & 0.712 & & \\
\hline Perceived Psychological Risk & & & & 0.932 & 15.457 \\
\hline PPR3 & 4.14 & 1.198 & 0.881 & & \\
\hline PPR2 & 4.30 & 1.143 & 0.829 & & \\
\hline PPR1 & 4.28 & 1.159 & 0.776 & & \\
\hline Halal Product Knowledge & & & & 0.802 & 14.209 \\
\hline KNW2 & 4.26 & 0.919 & 0.859 & & \\
\hline KNW3 & 4.41 & 0.829 & 0.831 & & \\
\hline KNW1 & 4.08 & 1.023 & 0.731 & & \\
\hline KNW4 & 3.51 & 1.093 & 0.536 & & \\
\hline Halal Awareness & & & & 0.793 & 12.747 \\
\hline HA2 & 3.13 & 1.371 & 0.841 & & \\
\hline HA3 & 3.88 & 1.3 & 0.739 & & \\
\hline HA1 & 3.72 & 1.232 & 0.685 & & \\
\hline Total Variance Explain & & & & & \\
\hline
\end{tabular}


The Cronbach's alpha values for the variables used in the study are $\alpha=0.938$ for purchase intention, $\alpha=0.901$ for attitude towards halal products, $\alpha=0.932$ for perceived psychological risk, $\alpha=0.802$ for knowledge about halal products, and $\alpha=0.793$ for halal awareness. The results of reliability analysis are well above the acceptable value of " 0.70 " and it can be said that the scales used in the questionnaire are reliable (Nunnally, 1978). The result of Kaiser-Meyer-Olkin (KMO) test is 0.924 and it can be said that the data set is suitable for analysis.

\subsection{Confirmatory Factor Analysis and Structural Model}

After exploratory factor analysis (EFA), confirmatory factor analysis (CFA) was performed followed by structural equation modeling (SEM). It was found that the data obtained as a result of CFA were within the acceptable range of goodness of fit (Doll et al., 1994: 456; Mishra \& Datta, 2011: 40). The values of average variance extracted (AVE) and composite reliability (CR), which are the values indicating the reliability of the model and goodness of fit of the research model, are presented in Table 2 below.

Table 2. AVE, CR Values and $R^{2}$ of the Structural Model

\begin{tabular}{lllc}
\hline & AVE & CR & $\mathrm{R}^{2}$ \\
\hline Halal Product Knowledge & 0.533 & 0.818 & \\
\hline Halal Awareness & 0.564 & 0.793 & 0.404 \\
\hline Attitude Towards Halal Product & 0.701 & 0.904 & 0.477 \\
\hline Perceived Psychological Risk & 0.822 & 0.933 & 0.179 \\
\hline Purchase Intention & 0.806 & 0.943 & 0.685 \\
\hline Goodness of fit: $\chi 2=392.621, d f=125, p=0.000, C M I N / D F=3.141, p=0.000, G F I=0.900, A G F I$ \\
$=0.863, N F I=0.933, T L I=0.953, C F I=0.953, R M S E A=0.077$ & & \\
\hline
\end{tabular}

On examining the results, it can be seen that the values of AVE are above 0.50 and the values of CR are above 0.70 . Therefore, as a result of the analysis, it was found that the model is suitable for structural model testing and the hypotheses can be tested. The structural model of the study is shown in Figure 2 .

Figure 2. Structural Equation Model

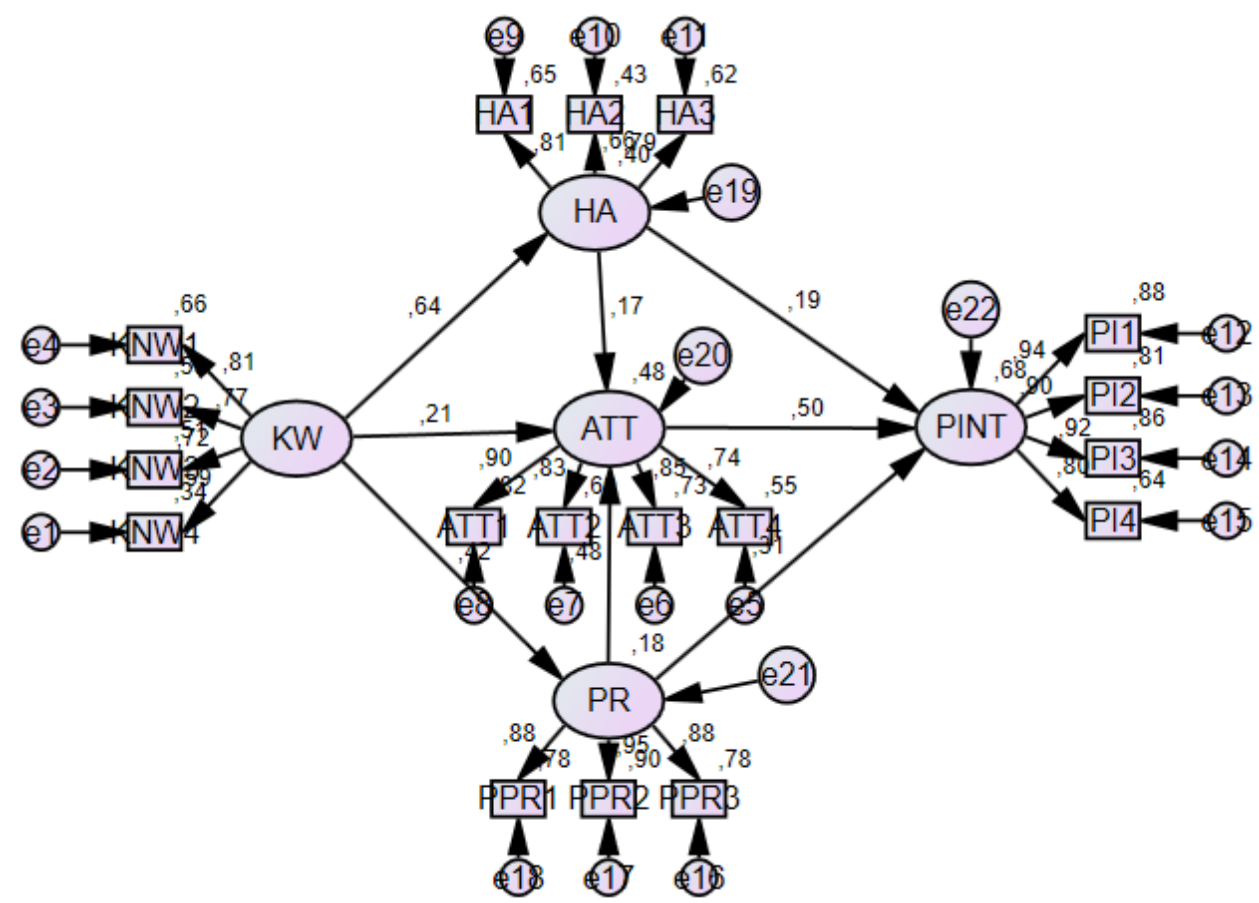


The $p$-values and standardized regression weights in Table 3 are examined to determine the relationships among the variables in the research model and to interpret the hypotheses. The decision to accept or reject a hypothesis is made using the $p$-value. The standardized regression weights are used to evaluate the extent to which one variable affected the other variable.

Table 3. Table of Hypothesis Tests

\begin{tabular}{lcccc}
\hline & Hypotheses & Standardized Regression Weights & $\mathrm{P}$ & Results \\
\hline $\mathrm{H}_{1}$ & $\mathrm{HA}<---\mathrm{KW}$ & 0.636 & $* * *$ & Accepted \\
$\mathrm{H}_{2}$ & $\mathrm{PR}<---\mathrm{KW}$ & 0.423 & $* * *$ & Accepted \\
$\mathrm{H}_{3}$ & ATT<---KW & 0.213 & 0.002 & Accepted \\
$\mathrm{H}_{4}$ & $\mathrm{~A} T \mathrm{C}<--\mathrm{HA}$ & 0.171 & 0.008 & Accepted \\
$\mathrm{H}_{5}$ & $\mathrm{ATT}<---\mathrm{PR}$ & 0.476 & $* * *$ & Accepted \\
$\mathrm{H}_{6}$ & PINT<---ATT & 0.502 & $* * *$ & Accepted \\
$\mathrm{H}_{7}$ & PINT<---HA & 0.187 & $* * *$ & Accepted \\
$\mathrm{H}_{8}$ & PINT<---PR & 0.309 & $* * *$ & Accepted
\end{tabular}

$p<0.05$, (KW: Halal Product Knowledge, HA: Halal Awareness, ATT: Attitude Towards Halal Product, PR: Perceived Psychological Risk, PINT: Purchase Intention)

Examination of the results shows that all the hypotheses of the model are accepted. Knowledge of halal products has a significant and positive effect on halal awareness and perceived psychological risk. Halal awareness and perceived psychological risk have a significant and positive effect on attitude towards halal products and purchase intention. Attitude towards halal products has a significant and positive effect on purchase intention.

\section{Conclusion}

Based on the statement on packaged food in Turkey that "no lard is used in our products"; it is assumed that the products are halal. However, in the case of meat products, the situation cannot be so easily overlooked because most food adulteration occurs in meat products. Therefore, the consumer perceives a greater risk with meat products (Ireland \& Rajabzadeh, 2011). It is not possible for consumers to tell if meat products are halal by touching, smelling, or looking at them. At this point, the only tool that consumers can trust is the food certificates issued by official institutions. Companies that use the halal logo on their packaging and receive a halal certificate have thereby declared that the product is halal. Thereafter, it is up to the consumer to research and confirm whether the product is suitable for halal conditions. The need for consumer confirmation depends on their knowledge and awareness of halal. However, the most important point is the information about halal products. This is because the availability and level of this knowledge will affect the whole consumer buying process. In some studies, it has also been found that the level of religiosity also has an impact on the purchase process (Rizkitysha \& Hananto, 2020; Mortimer et. al., 2020; Abd Rahman et al., 2015). In this study, it was predicted that knowledge about halal products in a country where the majority of the population is Muslim will have an effect on the purchase intention under the KAP model. Therefore, it is assumed that halal knowledge has an influence on consumer awareness, attitude, and perceived risk. Based on this assumption, it is assumed that halal awareness, attitude, and perceived risk have an effect on consumers' intention to purchase halal products. All the hypotheses made in the KAP model were accepted. The results obtained are in line with the literature. Awareness of halal products (Akın \& Okumuş, 2021) and knowledge about halal products (Rizkitysha \& Hananto, 2020) have an effect on attitude towards halal products. In addition, awareness of halal products (Nurhayati \& Hendar, 2019) and attitude towards halal products (Abd Rahman et al., 2015; (Öztürk et al., 2015; (Özçelik Yorulmaz \& Akçi, 2020) affect purchase intention. Al-Ansi et al. (2019) concluded that perceived psychological risk affects the attitude and intention towards the halal product. On the other hand, Bashir (2019) found that awareness of halal products has an effect on attitude and intention towards halal products. 
Consumers living in a Muslim country assume that all meat products are halal (Rizkitysha \& Hananto, 2020: 18). Therefore, there is no need to question whether meat products are halal or not. However, sometimes this trust and unquestioning of consumers in producers causes some malicious companies to engage in unethical practices (Ireland \& Rajabzadeh, 2011). Although the legal penalties are deterrent in this regard, such companies pop up at all times. In order to prevent this, a certification system should be introduced which is controlled and monitored by the government. Businesses holding the certificate should be given the right to use the halal logo approved by the state. Subsequently, it is recommended that businesses educate consumers about this halal certificate and logo. In this way, consumers will know that the most reliable way to reduce risk is to buy products with halal logo (Hartmann \& Apaolaza-lbáñez, 2012). The idea that Halal means eating and drinking only according to Islamic rules will limit the concept. Halal also means being clean and hygienic. Thus, consumers who are looking for halal products are not only looking for products that comply with Islamic rules, but also for clean and healthy products. Given consumer awareness, companies that want to participate in the growing halal market should differentiate themselves from their competitors, pay attention to halal at every stage from product manufacturing to post-purchase, and inform their consumers about these practices.

The increase in the Muslim population and the market for halal food has sparked corporate interest in this market. However, it is believed that this interest is not reaching the level that businesses in Muslim countries expect. In particular, companies in Muslim countries need to rid themselves of marketing myopia regarding halal food.

The possibility of fraud in meat products creates a major consumer confidence problem. Companies think they can fill this gap with brand trust. However, the phenomenon of halal food in Muslim societies is a very important tool to fill the trust gap. While halal food is perceived as hygienic, high quality, and safe even by non-Muslim consumers (Aziz \& Chok, 2013), this perception is yet to be fully embraced by consumers in Muslim countries. The halal concept can be identified by companies with terms such as organic and healthy, and it can also respond to demand in this area. Companies can gain a competitive advantage by taking various measures (e.g. labels, logos, and statements highlighting the halal concept in retail spaces and on the packaging, etc.) rather than waiting for consumers to develop halal awareness on their own. In addition, messages explaining halal criteria can be conveyed to consumers with the stalls they set up on TV or in radio advertisements and at points of sale. It is recommended that companies point out in their messages that halal products are not only products that meet religious criteria, but also clean, organic, and healthy products.

Companies want to engage consumers, who have become more aware in recent years, from the production process to the final purchase process and beyond. They go even further and support the entire process from table to fork with blockchain technology. Such companies use the code system QR to create a positive customer experience that allows customers to track the entire journey of the product in a transparent manner. To ensure this trust, some meat producers record all production processes with cameras and broadcast them live. Companies that can provide confidence in their customers by using these technologies along with the halal production process will be able to gain a significant competitive advantage. Companies that can meet these standards have the opportunity to increase their share of the non-Muslim consumer markets that have shown interest in halal food in recent years.

The results of the study show that consumers' halal awareness, attitude towards halal products, and perceived psychological risk of halal products are increasing. The increased awareness of the consumer with this perceived risk enables them to develop a positive attitude towards halal products. One of the striking findings of the study is that consumers with higher halal knowledge perceive more risks and are more concerned about whether the products are halal. This is because consumers with increasing halal knowledge question and pay more attention to the halal status of products. Consumers who want to reduce this perceived risk, on the other hand, intend to use the products that they know are halal.

The sample of this study was obtained using convenience sampling, which is a non-random sampling method. Therefore, the results to be obtained apply only to the sample and cannot be generalized to the entire study population. Since this study was conducted in Rize, Turkey, where the majority of the population 
is Muslim, the entire sample is limited to Muslim consumers. Furthermore, since it is assumed that all products in Turkey are halal, being in a Muslim country may have some influence on perceptions, attitudes, and behaviors.

It has been argued in the literature that the halal logo is the most important tool to prove to the consumer that the product is halal and to develop a positive attitude towards the product. It has also been found that halal knowledge and awareness play a key role in the intention to purchase halal products. Based on this information, the use of logos, labels, and signs that better explain halal slaughter to increase awareness, in addition to the halal logo, will give companies a competitive advantage. In future studies, examining the effects of these additional explanatory signs on halal awareness will contribute to the literature as well as provide guidance for businesses.

\section{Declarations and Disclosures}

Ethical Responsibilities of Authors: The author of this article confirms that her work complies with the principles of research and publication ethics.

Ethical Approval: Ethical approval was obtained from Recep Tayyip Erdoğan University Social Sciences and Humanities Ethics Committee, dated 20/04/2021, and Meeting Decision Number 2021/103.

Conflicts of Interest: No potential conflict of interest was reported by the author.

Funding: The author received no financial support for the preparation and/or publication of this article.

Author Contributions: The author confirms sole responsibility for conceptualization and design, data collection, analysis of data and interpretation of results, writing the first draft of the manuscript, and review and editing.

Plagiarism Checking: This article was screened for potential plagiarism using a plagiarism screening program.

\section{References}

Abd Rahman, A., Asrarhaghighi, E., \& Ab Rahman, S. (2015). Consumers and halal cosmetic products: Knowledge, religiosity, attitude and intention. Journal of Islamic Marketing, 6(1), 148-163.

Aertsens, J., Mondelaers, K., Verbeke, W., Buysse, J., \& Van Huylenbroeck, G. (2011). The influence of subjective and objective knowledge on attitude, motivations and consumption of organic food. British Food Journal, 113(11), 1353-1378.

Afendi, N. A., Azizan, F. L., \& Darami, A. I. (2014). Determinants of halal purchase intention: Case in Perlis. International Journal of Business and Social Research, 4(5), 118-123.

Ahmad, J., Noor, S. M., \& Ismail, N. (2015). Investigating students' environmental knowledge, attitude, practice and communication. Asian Social Science, 11(16), 284-293.

Akın, M. S., \& Okumuş, A. (2021). Shaping the consumers' attitudes towards Halal food products in Turkey. Journal of Islamic Marketing, 12(6), 1081-1096.

Al-Ansi, A., Olya, H. G., \& Han, H. (2019). Effect of general risk on trust, satisfaction, and recommendation intention for halal food. International Journal of Hospitality Management, 83, 210-219.

Alam, S. S., \& Sayuti, N. M. (2011). Applying the theory of planned behavior (TPB) in halal food purchasing. International Journal of Commerce and Management, 21(1), 8-20.

Amin, H. (2013). Factors influencing Malaysian bank customers to choose Islamic credit cards: Empirical evidence from the TRA model. Journal of Islamic Marketing, 4(3), 245-263.

Ambali, A. R., \& Bakar, A. N. (2014). People's awareness on halal foods and products: Potential issues for policy-makers. Procedia-Social and Behavioral Sciences, 121, 3-25

Arshia, M., \& Mohsin, M. (2012). Intention to choose halal products: The role of religiosity. Journal of Islamic Marketing, $3(2), 1-11$.

Ashford, R., Cuthbert, P., \& Shani, N. (2000). Perceived risk and consumer decision making related to health services: A comparative study. International Journal of Nonprofit and Voluntary Sector Marketing, 5(1), 58-72. 
Aziz, Y. A., \& Chok, N. V. (2013). The role of halal awareness, halal certification, and marketing components in determining halal purchase intention among non-Muslims in Malaysia: A structural equation modeling approach. Journal of International Food \& Agribusiness Marketing, 25(1), 1-23.

Baser, F., Ture, H., Abubakirova, A., Sanlier, N., \& Cil, B. (2017). Structural modeling of the relationship among food safety knowledge, attitude and behavior of hotel staff in Turkey. Food Control, 73, 438-444.

Bashir, A. M. (2019). Effect of halal awareness, halal logo and attitude on foreign consumers' purchase intention. British Food Journal, 121(9), 1998-2015.

Bonne, K., \& Verbeke, W. (2008). Religious values informing halal meat production and the control and delivery of halal credence quality. Agriculture and Human Values, 25(1), 35-47.

Bergeaud-Blackler, F., Fischer, J., \& Lever, J. (2016). Halal matters: Islam, politics and markets in global perspective. New York, NY: Taylor and Francis.

Bauer, R. A. (1960). Consumer behavior as risk taking. In R.S. Hancock (Ed.), Dynamic marketing for a changing world, Proceedings of the 43rd. National Conference of the American Marketing Association, AMA, Chicago, pp.389398.

Burgmann, T. (2007). Growing Muslim population pushing companies to produce product they can eat. The Star, Online version. Retrieved April 01, 2021, from www.thestar.com/Business/article/238551

Bonne, K., Vermeir, I., Bergeaud-Blackler, F., \& Verbeke, W. (2007). Determinants of halal meat consumption in France. British Food Journal, 109(5), 367-386.

Chen, Y. J., \& Tang, T. L. P. (2013) The bright and dark sides of religiosity among university students: Do gender, college major and income matter? Journal of Business Ethics, 115(3), 531-553.

Çukadar, M. (2017). Helal gıda konusunda tüketici davranışları. Gaziosmanpaşa Üniversitesi Ziraat Fakültesi Dergisi, $34(3), 190-200$.

Dindyal, S., \& Dindyal, S. (2003). How personal factors, including culture and ethnicity, affect the choices and selection of food we make? Internet Journal of Third World Medicine, 1(2), 27-33.

Doll, W., Xia W., \& Torkzadeh, G. (1994). A confirmatory factor analysis of the end-user computing satisfaction instrument. MIS Quarterly, 18(4), 453-461.

Fishbein, M., \& Ajzen, I. (1975). Belief attitude, intention and behavior. an introduction to theory and research, reading. MA: Addison Wesley Publishing Company.

Fuseini, A., Wotton, S. B., Knowles, T. G., \& Hadley, P. J. (2017). Halal meat fraud and safety issues in the UK: A review in the context of the European Union. Food Ethics, 1(2), 127-142.

GIMDES, (2021). White Meat (Chicken and Turkey). Retrieved December 14, 2021, from http://www.gimdes.com/KategoriListe/beyaz-et--tavuk-ve-hindi---white-meat--chicken-and-turkey-__15

Golnaz, R., Zainulabidin, M., Mad Nasir, S., \& Eddie Chiew, F. C. (2010). Non-Muslim perception awareness of halal principle and related food products in Malaysia. International Food Research Journal, 17(3), 667-674.

Hartmann, P., \& Apaolaza- Ibáñez, V. (2012). Consumer attitude and purchase intention toward green energy brands: The roles of psychological benefits and environmental concern. Journal of Business Research, 65(9), 1254-1263.

Helal Platform, (2018). Helal sertifikası veren firmalar. Retrieved December 14, 2021, from http://www.helalplatform.com/helal-gida-sertifikasi-veren-firmalar.html

Hoyer, W. D., \& Deborah, J. M. (2007). Consumer behavior. Boston, USA: Houghton Mifflin Company.

International Halal Certification, (2021). What is halal? Retrieved April 23, 2021, from https://internationalhalal.com/why-halal-certification/\#whatishalal

Ireland, J., \& Rajabzadeh, S. A. (2011). UAE consumer concerns about halal products. Journal of Islamic Marketing, 2(3), 274-283.

Karaman, H., Çağrıcı, M., Dönmez, İ. K., \& Gümüş, S., (2013). Kuran yolu türkçe meal ve tefsir (5 Cilt). T.C. Diyanet İşleri Başkanlığı Yayınları.

Kim, L. H., Kim, D. J., \& Leong, J. K. (2005). The effect of perceived risk on purchase intention in purchasing airline tickets online. Journal of Hospitality and Leisure Marketing, 13(2), 33-53.

Kızgın, Y., \& Özkan, B. (2014). A study on determining the halal food consumption tendencies of the consumers. Business \& Management Studies: An International Journal, 2(1), 18-37.

Kurtoğlu, R., \& Çiçek, B. (2013). Tüketicilerin helâl ürünler hakkındaki algılama, tutum ve beklentilerini tespit etmeye yönelik bir araştırma. Eskişehir Osmangazi Üniversitesi iiBF Dergisi, 8(3), 181-205. 
Kwol, V. S., Eluwole, K. K., Avci, T., \& Lasisi, T. T. (2020). Another look into the Knowledge Attitude Practice (KAP) model for food control: An investigation of the mediating role of food handlers' attitudes. Food Control, 110, 107025. https://doi.org/10.1016/j.foodcont.2019.107025

Lada, S., Harvey Tanakinjal, G., \& Amin, H. (2009). Predicting intention to choose halal products using theory of reasoned action, International Journal of Islamic and Middle Eastern Finance and Management, 2(1), 66-76.

Launiala, A. (2009). How much can a KAP survey tell us about people's knowledge, attitudes and practices? Some observations from medical anthropology research on malaria in pregnancy in Malawi. Anthropology Matters, 11(1), 1-13.

Loho, P. (2020). In 2020, German companies increasingly invested in halal. Retrieved April 20, 2021, from https://www.salaamgateway.com/story/in-2020-german-companies-increasingly-invested-in-halal

Madenci, A. B., Bayramoğlu, Z., Türker, S., Ağizan, K., \& Vildan, E. Y. I. Z. (2020). Determination of consumer's willingness to pay for halal food. Tekirdağ Ziraat Fakültesi Dergisi, 17(3), 346-356.

Mishra, P., \& Datta, B. (2011). Perpetual asset management of customer-based brand equity-The PAM evaluator. Current Research Journal of Social Sciences, 3(1), 34-43.

Mutmainah, L. (2018). The role of religiosity, halal awareness, halal certification, and food ingredients on purchase intention of halal food. Journal of Islamic Economics, Finance, and Banking, 1(1), 33-50.

Mitchell, V. (1999). Consumer perceived risk: Conceptualizations and models. European Journal of Marketing, 33(1), 163-195.

Mortimer, G., Fazal-e-Hasan, S. M., Grimmer, M., \& Grimmer, L. (2020). Explaining the impact of consumer religiosity, perceived risk and moral potency on purchase intentions. Journal of Retailing and Consumer Services, 55, 102115.

Nurhayati, T., \& Hendar, H. (2019). Personal intrinsic religiosity and product knowledge on halal product purchase intention: Role of halal product awareness. Journal of Islamic Marketing, 11(3), 603-620.

Nunnally, J. C. (1978). Psychometric theory. New York: McGraw-Hill (PewInternet).

OECD, (2021). Meat consumption (indicator). doi: 10.1787/fa290fd0-en (Accessed on 02 May 2021), https://data.oecd.org/agroutput/meat-consumption.htm

Özçelik Yorulmaz, D., \& Akçi, Y. (2020). Helal gıda tüketimine yönelik tutumların satın alma niyeti üzerindeki etkisi (Adıyaman örneği). Kahramanmaraş Sütçü Imam Üniversitesi Sosyal Bilimler Dergisi, 17(2), 1218-1238.

Özdemir, H., \& Yaylı, A. (2014). Tüketicilerin helâl sertifikalı ürün tercihleri üzerine bir araştırma: İstanbul ili örneği. İşletme Araştırmaları Dergisi, 6(1), 183-202.

Öztürk, A., Nart, S., \& Altunışık, R. (2015). Tüketicilerin helal tüketim davranışlarının belirleyicileri: Planlı Davranış Teorisi çerçevesinde bir araştırma. International Journal of Islamic Economics and Finance Studies, 1(2), 141-160.

Quintal, V., Phau, I., Sims, D., \& Cheah, I. (2016). Factors influencing generation Y's purchase intentions of prototypical versus me-too brands. Journal of Retailing and Consumer Services, 30, 175-183.

ResearchAndMarkets, (2020). Halal food market: Global industry trends, share, size, growth, opportunity and forecast 2021-2026. Retrieved April 03, 2021, from https://www.researchandmarkets.com/reports/5311860/halal-foodmarket-global-industry-trends-share\#

Rizkitysha, T. L., \& Hananto, A. (2020). Do knowledge, perceived usefulness of halal label and religiosity affect attitude and intention to buy halal-labeled detergent? Journal of Islamic Marketing, Vol. ahead-of-print No. ahead-ofprint. https://doi.org/10.1108/JIMA-03-2020-0070

Rogers, E. M. (2003). Diffusion of innovations (5th ed.). New York: Free Press.

Schiffman, L. G., \& Kanuk, L. L. (2004). Consumer behaviour (8th ed.). Upper Saddle River, NY.: Pearson Education.

Statista, (2021a). Market value of halal foods worldwide from 2017 to 2023. Retrieved April 01, 2021, from https://www.statista.com/statistics/562857/market-value-of-halal-products-worldwide/

Statista, (2021b). Leading exporters of halal foods to Organisation of Islamic Cooperation countries in 2019. Retrieved December 01, 2021, from https://www.statista.com/statistics/785151/top-exporters-of-halal-food-global/

Stone, R. N., \& Mason, B. J. (1995). Attitude and risk: Exploring the relationship. Psychology and Marketing, 12(2), 135153.

Shah Alam, S., Mohd, R., \& Hisham, B. (2011). Is religiosity an important determinant on Muslim consumer behaviour in Malaysia? Journal of Islamic Marketing, 2(1), 83-96. 
Stobbelaar, D. J., Casimir, G., Borghuis, J., Marks, I., Meijer, L., \& Zebeda, S. (2007). Adolescents' attitudes towards organic food: A survey of 15 to 16 year old school children. International Journal of Consumer Studies, 31(4), 349356.

Salaam Gateway, (2020). State of the Global Islamic Economy 2020/21 Report. Retrieved April 10, 2021, from https://www.salaamgateway.com/specialcoverage/SGIE20-21

Taha, S., Osaili, T. M., Vij, A., Albloush, A., \& Nassoura, A. (2020). Structural modelling of relationships between food safety knowledge, attitude, commitment and behavior of food handlers in restaurants in Jebel Ali Free Zone, Dubai, UAE. Food Control, 118, 107431.

The Holy Quran, Surah Al-Baqarah (The Cow); Surah: 2, verse: 168 and 173. Retrieved April 01, 2021, available online from: https://quran.com/2

The Holy Quran, Surah Al-Ma'idah (The Table Spread); Surah: 5, verse: 88. Retrieved April 01, 2021, available online from https://quran.com/5

The Holy Quran, Surah Al-An'am (The Cattle); Surah: 6, verse: 145. Retrieved April 01, 2021, available online from: https://quran.com/6

Directorate of Agricultural Economy and Policy Development Institute of the Ministry of Agriculture and Forestry of Turkish Republic, (2021). Tarım ürünleri piyasaları tavuk eti, Haziran 2021.

TURKSTAT, (2021, June). Kümes hayvancılığı üretimi. Retrieved December 24, 2021, from https://data.tuik.gov.tr/Bulten/Index?p=Kumes-Hayvanciligi-Uretimi-Haziran-2021-37220

Vanany, I., Hua Tan, K., Siswanto, N., Arvitrida, N. I., \& Pahlawan, F. M. (2021). Halal six sigma framework for defects reduction. Journal of Islamic Marketing, 12(4), 776-793.

Yasid, F. F., \& Andriansyah, Y. (2016). Factors affecting Muslim students' awareness of halal products in Yogyakarta, Indonesia. International Review of Management and Marketing, 6(4S), 27-31.

Zakaria, Z., Abdul Majid, M. D., Ahmad, Z., Jusoh, Z., \& Zakaria, N.Z. (2017). Influence of halal certification on customers' purchase intention. Journal Fundamentals Applications Sciences, 9(5S), 772-787. 
This Page Intentionally Left Blank 